\title{
LITERATURA E ENUNCIAÇÃO: O EU E O DUPLO, ENTRE NARRADOR-PROTAGONISTA E INTERLOCUTOR, EM GRANDE SERTÃO: VEREDAS
}

\author{
LITERATURE AND ENUNCIATION: THE SELF \\ AND THE DOUBLE, BETWEEN NARRATOR- \\ PROTAGONIST AND INTERLOCUTOR, IN GRANDE \\ SERTÁO: VEREDAS
}

\author{
Fabrício Magalhães de Souza \\ Secretaria de Estado de Educação e Desporto, Seduc, Manaus, AM, Brasil \\ Juciane dos Santos Cavalheiro \\ Universidade do Estado do Amazonas, UEA, Manaus, AM, Brasil
}

Resumo: Da leitura de Grande sertão: veredas, este trabalho faz uma análise do duplo a partir do narrador-protagonista e o seu interlocutor. Tem como sustentaçáo teórica o estudo realizado por Nicole Bravo (1998), que analisa o duplo como um mito literário característico da literatura ocidental e defende seu surgimento atrelado à experiência subjetiva; assim como o estudo do sistema pronominal de Émile Benveniste (1989; 1991): verificaremos como a presença do duplo no um é a sustentação para configuração da subjetividade do $e u$-protagonista a partir de sua relaçấo intersubjetiva com os outros personagens inseridos no ambiente narrativo/enunciativo.

Palavras-chave: GS:V; Duplo; Enunciação.

Abstract: From reading Grande sertão: veredas, this work analyzes the double from the narratorprotagonist and his interlocutor. It has as theoretical support the study carried out by Nicole Bravo (1998), which analyzes the double as a literary myth characteristic of western literature and defends its appearance linked to subjective experience; as well as the study of the pronominal system of Émile Benveniste (1989; 1991): we will check how the presence of the double in the one is the support for configuring the subjectivity of the self-protagonist from its intersubjective relationship with the other characters inserted in the narrative environment / enunciative.

Keywords: GS: V; Double; Enunciation.

Lançado em 1956, Grande Sertão: Veredas ${ }^{1}$, do escritor mineiro

${ }^{1}$ Doravante $G S: V$. As citaçóes utilizadas foram retiradas da $19^{\circ}$ edição publicada pela editora Nova Fronteira, em 2001. 
João Guimarães Rosa, é um romance narrado em primeira pessoa pelo exjagunço, Riobaldo, a um ouvinte letrado da cidade, a quem chama sempre de "senhor", cuja presença é perceptível pelas marcas que deixa em seu discurso (direto livre). O assunto norteador do diálogo é a guerra entre dois grupos de jagunços: os joca ramiros e os hermógenes. Ao contar sua história, Riobaldo faz parecer que o problema central dela gira em torno de terse ele mesmo tornado parte desse sistema, e que a guerra ocupa lugar de destaque em boa parte de sua narrativa. A disputa foi gerada por uma traição acontecida dentro do próprio grupo, quando o chefe Joca Ramiro é morto pelos jagunços de Hermógenes e Ricardão, antes seus aliados nas batalhas do sertão, e que fazem o bando se dividir.

Mas Riobaldo envereda por outros casos do sertáo e, principalmente, nas reflexóes que faz, demonstra um "tom narrativo de perplexidade e de reflexão", seja sobre um pacto com o demônio, que teria feito ou náo (a imprecisão e a dúvida fazem parte dessas memórias) seja, ainda, "pelo sentido de uma frustraçáo amorosa”: sua amizade com um dos companheiros de jagunçagem, Diadorim, o Reinaldo, a quem, em tom confessional, diz ter amado (MORAIS, s. d., p. 5).

A partir da leitura de $G S: V$, este trabalho faz uma análise do duplo a partir do eu-protagonista/narrador e o tu (o "senhor"), e a presença de um terceiro elemento a substanciar a narrativa, Reinaldo-Diadorim. Como suporte teórico-conceitual, utilizamos: a) a tríade benvenistiana: o $\mathrm{eu}$, o $\mathrm{tu}$ e o ele - o "eu" está conectado à presença (ao aqui e agora da enunciaçáo), e implica um interlocutor (o "tu"), pois "para ser um [eu], é preciso ser dois [eu e tu], mas quando se é dois, de imediato se é três [eu, tu e ele]", porque, para além da presença (manifesta pelo eu e tu), é preciso que a ausência [o ele] se faça presente, na medida em que "representa a todos os instantes a única perspectiva do homem” (DUFOUR, 2000, p. 55); e b) o duplo como uma experiência subjetiva, de acordo com os estudos realizados por Nicole Bravo (1998).

No momento de proferir eu, "o locutor" sempre "implanta o outro diante de si, qualquer que seja o grau de presença que atribua a este outro" (BENVENISTE, 1989, p. 84), porque toda alocuçáo ${ }^{2}$ postula um

2"a alocução é o tempo durante o qual um alocutório dado assume a forma "eu" diante de um "tu" (DUFOUR, 2000, p. 75). 
alocutório. Todavia, quando se analisa a constituição da subjetividade de um narrador intradiegético que dialoga sem interrupçôes, como ocorre em $G S: V$, o interlocutor, o senhor que anota o relato, descaracteriza-se, ou seja, não tem direito a tornar-se um $e u$ que possa enunciar, posto que permanece sem emitir resposta explícita durante toda a narrativa. Assim, onde se localizaria, no espaço enunciativo, o interlocutor? Quem é ele?

Bravo (1998), ao tratar do mito ancestral do duplo, mostra obras onde aparecem pistas linguísticas dele: "eu-outro-ele", "eu-dois em um", "eu-eu mesmo" (BRAVO, 1998, p. 261). O mito do duplo até certo tempo representava uma tendência à unidade [do $e u]$. Com o término do século XVI, escreve a ensaísta, "o duplo começa a representar o heterogêneo, com a divisão do eu chegando à quebra da unidade (século XIX) e permitindo até mesmo um fracionamento ao infinito (século XX)" (BRAVO, 1998, p. 264).

A explicação a essa evolução estaria na nova concepção do homem na natureza: "com a afirmação da independência do ego de Deus no século XVII", "o sujeito como centro do mundo [...] resultará na sua hipertrofia" (BRAVO, 1998, p. 264). Prossegue observando ainda que a "abertura para o espaço interior do ser, perspectiva que se inaugura no século XVII, força o abandono progressivo do postulado da unidade da consciência, da identidade de um sujeito, única e transparente" (BRAVO, 1998, p. 267). Bravo mostra que é "um conflito psíquico que cria o duplo", como "projeção da desordem íntima” (BRAVO, 1998, p. 263); "o eu soberano que se expressava no cogito dá lugar ao "quem fala por mim? [...] O sujeito descobriu sua brecha." (BRAVO, 1998, p. 279).

Ao narrar sua história, tendo o "senhor" como seu ouvinte, a quem continuamente se dirige: "o senhor ouviu"; "o senhor tolere"; "o senhor entenda”; "o senhor pergunte”; "o senhor não é como eu?” (ROSA, 2001, p. 25) - a categórica afirmação de Riobaldo

O senhor saiba: eu toda a minha vida pensei por mim mesmo, forro, sou nascido diferente. Eu sou é eu mesmo. Divêrjo de todo mundo... Eu quase que nada sei. Mas desconfio de muita coisa (ROSA, 2001, p. 31, grifo nosso).

mostrar-se-á problemática justamente pela própria presença desse interlocutor, uma vez que todas as possibilidades "de respostas, observaçôes, complementaçóes, perguntas" "são pressupostas" somente pelo narrador (MORAIS, s.d., p. 5). Seria o interlocutor de Riobaldo, de fato, outra 
pessoa ou o seu duplo?

Cleuza Passos (2008, p. 67) aponta que uma das causas do conflito interior de Riobaldo é o de não perceber que Diadorim era, afinal, uma mulher, o que conferiria coerência ao seu amor, contudo interditado, e o "(não)saber, nó da trajetória e sina a ser desenredada somente com a morte do objeto desejado, provoca o impulso de contar e ser escutado". Cleonice Mourão (2000) também observa que "o personagem Reinaldo, enquanto Diadorim, constitui um ponto de imantação que marca o texto, expandindo-o muito além da narrativa"; assim, $G S: V$ "é um espaço textual de uma excessiva dispersáo" e "Diadorim atua como princípio de desestabilizaçáo, produzindo a multiplicidade e a errância de uma história que poderia ser narrada em poucas páginas" (MOURÃO, 2000, p. 158159).

Se Riobaldo se vê sozinho tentando entender seus conflitos, pode ter criado um "outro imaginário". Nesses seus conflitos do alter-ego, configurarse-ia, então, em uma multiplicação de eus que garantiria a enunciação. O "senhor", deixando de descaracterizar-se, isto é, deixando de ser um interlocutor silencioso e diferente do narrador-protagonista, passa então a ser compreendido como um duplo do próprio narrador. $\mathrm{Na}$ fala de Riobaldo, sua enunciação só é possível pela presença desse outro. A todo momento é contado ao "senhor" o relato, mas a ele está interditado, pelo narrador, o direito à fala - e isso o caracteriza como um tu imaginário.

Se se encarar que a narração de Riobaldo é a problematização de um ego bifurcado, então está o leitor diante de um caso particular de confissão, em que o interlocutor/ouvinte, longe de ser um hóspede culto, ou a providência para a adoção de "uma longa fala em primeira pessoa que, mesmo presumindo a presença de um interlocutor, coloca-o em absoluto segundo plano ao dar voz ao protagonista" (COUTINHO, 2008, p. 381), estar-se-ia antes diante de um "dizedor/falador, como um aedo grego, que inscreve o que diz nos movimentos do que diz, [e] falando a partir de "nada", o narrador é alguém em luta com a linguagem, na travessia dos signos" (HANSEN, 2000, p. 45). Esse dizedor seria a enunciação de um sujeito (eu) que diz eu apropriando-se da língua e a enunciando a partir da posição de $e u$. Benveniste (1991, p. 286; 293), contudo, ao ancorar a subjetividade à língua, diz que, ao enunciar, o locutor instaura um interlocutor, o $t u$, e assim se estabelece a intersubjetividade na língua: "Eu não emprego eu a não ser dirigindo-me a alguém, que será na minha alocução um tu" e "é a língua enquanto assumida pelo homem que fala, e sob a condição de 
intersubjetividade, única que torna possível a comunicação lingüística”. Mas locutor e interlocutor se revezam no ato de enunciar, o que não acontece na narração de Riobaldo.

A primeira observação a ser notada na narrativa é que o narrador pronuncia enunciados unários ${ }^{3}$ "“eu sou é eu mesmo", "eu sou Riobaldo (eu)") enquanto fala ao seu ouvinte, de um $e u$ que a todo momento afirmase dono de toda a linguagem ${ }^{4}$ - e a recupera, a joga, briga com as palavras, com o sertão, com os judas, com o-que-não-existe (o demônio), com seu amor interditado por Diadorim. Acontece que os enunciados unários por si só não se bastam, eles se instalam aí, na sua afirmação, como uma dobra sobre si mesma, um predicado que retorna ao sujeito que enuncia. ${ }^{5}$

A primeira "saída" adotada é imaginar Riobaldo num processo de fala interior, um diálogo contínuo consigo mesmo ${ }^{6}$, ou como a fala de monólogo, "resultante da cisão do ego" (BENVENISTE, 1989, p. 88). Ao falar do quadro figurativo da enunciaçáo, Benveniste entende o monólogo como procedente à enunciação e que, "o que em geral caracteriza a enunciação é a acentuação discursiva com o parceiro, seja este real ou imaginado, individual ou coletivo" e, "não obstante a aparência, [o monólogo] como uma variedade de diálogo"7 (BENVENISTE, 1989, p. 87).

Todavia, o diálogo interior como diálogo entre eu-falante e eu-ouvinte

${ }^{3}$ Dufour $(2000$, p. 35, 36) escreve que o enunciado unário "dá a escutar, de modo geral, algo como uma 'gagueira' ('...sou...sou')" e que "Benveniste [...] definiu o sujeito falante por esta fórmula: 'é $e u$ quem diz $e u$ ".

${ }^{4}$ Hansen (2000) chama atenção para este fato escrevendo que Riobaldo "impondo sua versão do que narra [...], obriga, ironicamente, o ouvinte a uma situação de silêncio cúmplice [...] ele é o sujeito absoluto de sua própria ação narrada” (p. 49).

5"A forma unária ignora a negação, desconhece a diferença entre o sim e o não, o verdadeiro e o falso: ela funciona na denegação, a qual conserva o termo que exclui!” (DUFOUR, p. 38).

"O "monólogo" é um diálogo internalizado, formulado em "linguagem interior, entre um eu locutor e um eu ouvinte. Às vezes, o eu locutor é o único a falar; o eu ouvinte permanece entretanto presente; sua presença é necessária e suficiente para tornar significante a enunciação do eu locutor" (BENVENISTE, 1989, p. 87-88).

${ }^{7}$ Fantini (2003, p. 75), analisando a estrutura formal enunciativa em que só se ouvem as palavras do entrevistado/narrador, cria o neologismo monodiálogo, característica, na sua observação, do diálogo pela metade de Riobaldo. 
não se configura em Riobaldo ${ }^{8}$, posto que tem um destinatário a quem nomeia como "senhor", que o ouve (ou seja, aquele que seria o eu-ouvinte de Riobaldo é, antes, um tu-ouvinte; logo, o que seria um diálogo interior é um diálogo com um $t u$-imaginário). Pois, ao enunciar como $e u$, o narrador já interdita a voz desse seu ouvinte. Como efeito de linguagem produzido "na e pela enunciação" (BENVENISTE, 1989, p. 84) de eu-Riobaldo-narrador, o "senhor" não poderia também ser um "ele" só por não haver reversibilidade (troca entre locutor e interlocutor no ato enunciativo), mas sim ser um tu que é interditado de se tornar $e u$. E a necessidade de ser ouvido faz Riobaldo instalar à frente de si esse outro como o tu-interlocutor, o seu duplo, que será responsável por registrar sua própria fala ${ }^{10}$. Esse interlocutor de Riobaldo é traço/resultante de sua consciência.

Ter em $G S: V$ a preocupação em descobrir precisamente de quem se trata o ouvinte a quem o narrador-protagonista (Riobaldo) dirige-se ("o senhor", de "suma doutoraçáo"), pode levar ao seguinte questionamento: qual a importância em saber de quem se trata esse personagem, se seria realmente imprescindível fixá-lo no espaço enunciativo do testemunhador, uma vez que é levado em consideração que, "por trás dos panos", Riobaldo está mais preocupado em entender(-se n)o sertão, assim como seu amor interditado por Diadorim e a existência do demo, do mal em si e sua negação a um mundo a que ele era contrário, na sua essência?

${ }^{8}$ Morais (s.d., p. 5) observa que Riobaldo instaura um "semi-diálogo formalizado", que "finge um diálogo interior." Rosenfield (2006, p. 363), por outro lado, escreve também que "falar consigo pressupôe, no mínimo, uma distância em relação a si, o espaço ou intervalo do "seroutro", que é o reconhecimento da alteridade". Antes de tudo, a ensaísta mostra que é possível uma dupla leitura dessa fórmula (o diálogo interior): 1) o estranho (distanciamento em relação a si) vem a significar o reconhecimento da distância que separa o sujeito (persona, máscara) do seu ser-imediato; 2) o dialogo pressupóe, também o adiamento da fala do outro. Acreditamos que esse adiamento de fala em um diálogo nâo correspondido remete, justamente, a um interlocutor imaginário (o $t u$ ) que se trata do próprio desdobramento de Riobaldo, conforme falaremos mais adiante.

${ }^{9} \mathrm{Na}$ definição do Dicionário de Linguistica da enunciação (2009), organizado por Valdir N. Flores, Leci B. Barbisan; Maria José B. Finatto e Marlene Teixeira, o ele é a "face objetiva da língua" e "modo de enunciação possível para instâncias não pessoais" e que "na língua, tudo o que não é do domínio de eu-tu, pertence ao domínio do ele, da não pessoa." (2009, p. 174).

${ }^{10}$ Luis Oliveira (2008, p. 16) escreve que o interlocutor "é um fiador da verossimilhança do romance” e será assim responsável pela transcrição do mesmo. 
Kathrin Rosenfield (2006, p. 362) aponta que o "discurso direto dirigido ao senhor é permanentemente reatualizado pelas perguntas e suposições do narrador" e que ele "configura assim uma situação dialógica cuja particularidade consiste apenas na ausência de atualização da segunda voz, pelo silêncio do senhor". Assim, é a não resposta direta do "senhor" que vai modulando o discurso do narrador, uma vez que ele dá continuidade ao diálogo fazendo ele mesmo essa atualizaçáo dentro da sua própria enunciação, o que poderia soar, num primeiro instante, como um diálogo interior entre "eu falante" e "eu ouvinte", e assim supor que o "eu falante" interpela seu "eu ouvinte" usando a segunda pessoa - o $t u^{11}$; contudo, o uso desse índice é apenas um simulacro do $e u$, mas não de um $e u$ vindo do diálogo interior, mas de um duplo do narrador, um eu duplicado: eu-eu mesmo (Riobaldo), eu (Riobaldo)-tu ("senhor"), pois esse interlocutor está presente como um diferente de si mesmo (o narrador).

É assim que, pelas pistas dadas por Riobaldo, o interlocutor/ouvinte é caracterizado por certas particularidades: ele conhecia o comerciante Wulpes, amigo de Riobaldo: "[...] Ah, o senhor conheceu ele? Ô tiquinha de mundo! E como é mesmo que o senhor frasêia? Wusp?” (ROSA, 2001, p. 87); "interrompe" a narrativa para indagar algo que não entendera do relato (todavia, o leitor não "ouve" voz nenhuma): "Estradas vão para as Veredas Tortas - veredas mortas. Eu disse, o senhor não ouviu. Nem torne a falar nesse nome, não. É o que ao senhor lhe peço.” (ROSA, 2001, p. 113); tem até um bom meio de transporte para adentrar o sertão: "[...] Ao mais que, no carro-de-bois, levam muitos dias, para vencer o que em horas o senhor em seu jipe resolve [...]" (ROSA, 2001, p. 118); e o narrador pede até que ele trace mapas: "[...] os lados do lugar, definir para o senhor? Só se a uso de papel, com grande debuxo. O senhor forme uma cruz, traceje. Que tenha os quatro braços, e a ponta de cada braço: cada uma é uma..." (ROSA, 2001, p. 563).

Mesmo interditado em sua fala (tornar-se eu), Rosenfield (2006, p. 363) mostra que "a posição do senhor está assegurada ao longo do texto, ele está ficcionalmente presente até o final do romance” e que "embora não adquira a plasticidade de um caráter individualizado", não pode ser negligenciado. Nesse sentido, a ensaísta mostra que "o silêncio

\footnotetext{
${ }^{11 B e n v e n i s t e ~(1989, ~ p . ~ 88) ~ o b s e r v a ~ q u e, ~ n o ~ d i a ́ l o g o ~ i n t e r i o r, ~ o r a ~ " o ~ e u ~ o u v i n t e ~ s u b s t i t u i ~ o ~ e u ~}$ locutor e se enuncia como "primeira pessoa"”, ora "o eu ouvinte interpela na "segunda pessoa" o eu locutor". Ele mostra também que em línguas como o alemão e o russo, o eu ouvinte pode pôr-se como parceiro de diálogo e empregando $t u$, quando se tratar da transposição de diálogo em monólogo.
} 
não é ausência, mas presença negativa". Sua interpretação aproxima-se da observação feita por João Adolfo Hansen (2000, p. 48-49) que, ao analisar o início da narrativa

- Nonada. Tiros que o senhor ouviu foram de homem náo. Deus esteja. Alvejei mira em árvore, no quintal, no baixo do córrego. Por meu acerto. Todo dia isso faço, gosto; desde mal em minha mocidade (ROSA, 2001, p. 23).

mostra que a fala de Riobaldo "faz como esforço de vencer o outro, incorporando-o, neutralizando-o: ágon, fala agônica" e que "esse "nonada" inicial [...]" é marca da negatividade e da denegação do texto, e "indicia o discurso agônico que, em todos os seus movimentos, tem nítida consciência da fala e também das representaçóes do outro e, por isso, cala-o" (HANSEN, 2000, p. 48-49).

O que ocorre anteriormente a esse acontecimento enunciativo em que tudo é falado a partir de uma negação à indagaçáo do interlocutor (nonada pode significar "náo nada", "nada disso") - não é dado a conhecer ao leitor, esse já é pego de surpresa, confia-se, tão somente, no testemunho do narrador-protagonista, que não deixa outro falar, a não ser ele mesmo.

O "senhor", como é de fora - da cidade, dá a Riobaldo o conforto de que, assim que terminar de ouvir o relato-confissáo, irá embora, de modo que se afigura como "um segundo proveito: faz do jeito que eu falasse mais mesmo comigo" (ROSA, 2001, p. 55). Também confessa que "o que é ruim, dentro da gente, a gente perverte sempre por arredar mais de si. Para isso é que muito se fala?” (ROSA, 2001, p. 55). A fala de Riobaldo contracena, logo, como uma fala de "contradiçôes", que vão se entretecendo continuamente.

Riobaldo continua a narração a fim de expor as indagaçóes que o ouvinte anterior - o compadre Quelemém, que emprestara os ouvidos a ele, antes do ilustre visitante - ainda não o haviam aquietado: "Compadre meu Quelemém me hospedou, deixou meu contar minha história inteira" (ROSA, p. 623).

Do começo ao fim, uma coisa fica confirmada: a viagem do "senhor" pelo sertão é feita via relato: ele ouve, ele viaja, ele conhece o sertão, e o sertão está na palavra, o sertão é a palavra, que enche o cômodo no lugar em que está Riobaldo, "sentado na sua cadeira grandalhona de espreguiçar, entre um gole e outro de café, uma pitada de cigarro, onde vai reforçando seus 
dias, repensando" (ROSA, p. 325). É interessante que Rosenfield (2006, p. 359-360) amplia essa existência ou vivência via discurso ao escrever que, na "matriz formal da narrativa" é o discurso "que atribui posiçôes nas quais os personagens surgem progressivamente" e, na instância da persona autoral, "Riobaldo é nada mais do que a ficção resultante de um jogo discursivo" e, por isso, nem Riobaldo e o "senhor" existem, mas surgem "como projeção de um discurso que lhe[s] é atribuído pelo autor."

Marli Fantini (2003, p. 275-276) mostra também outra faceta desse narrador: a par de seu interlocutor ser letrado (o "senhor" com "suma doutoração"), "a fala" de Riobaldo trata-se "de um logro, visto Riobaldo fazer-se insciente e fazer indagaçốes acerca de aporias existenciais e metafísicas sobre as quais ele paradoxalmente [...] se mostra dotado de profunda sabedoria", em contrapartida à sua afirmação de "ser pobre coitado" (ROSA, 2001, p. 30).

A interdição feita ao "senhor" (seja a neutralização de sua fala feita pelo narrador já de início, seja a não reatualização de sua voz) não representa apenas um recurso para o outro náo falar, mas porque esse outro é um desdobramento da consciência fragmentada do próprio Riobaldo. Esse "senhor" constitui-se, assim, como um efeito de linguagem do narrador que, ao iniciar seu relato, se recolhe do mundo, pois gostava de estar sozinho, "sempre nas estreitas horas" (ROSA, 2001, p. 169).

A grande problemática que se descortina ao longo da narrativa de Riobaldo envolve a própria constituição de sua subjetividade ${ }^{12}$ na sua relação com os demais personagens do seu relato. Se, conforme Passos (2008, p. 77), Riobaldo conta "um passado ainda em reelaboração", certo é também que ele, como sujeito, está em processo de "construção"13 de si, fato este reiterado pelo próprio narrador em alguns fragmentos de sua narração:

\footnotetext{
${ }^{12} \mathrm{O}$ termo a ser considerado aqui é o apontado pela teoria benvenistiana: "A subjetividade é a passagem de locutor a sujeito e essa passagem se apresenta na língua através de marcas específicas que estáo no campo da categoria de pessoa" (FLORES; BARBISAN; FINATTO; TEIXEIRA, 2009, p. 219-220).

${ }^{13}$ Deise Pimentel (2003, p. 136) observa, ao analisar as transformaçôes de Riobaldo ligadas aos seus nomes (Baldo, Professor, Cerzidor, Tatarana, Urutu-Branco) que a "problemática do "homem em construção" é sempre retomada na obra de Guimarães Rosa".
} 
O senhor... Mire veja: o mais importante e bonito, do mundo, é isto: que as pessoas não estão sempre iguais, ainda náo foram terminadas - mas que elas vão sempre mudando. Afinam ou desafinam. Verdade maior. É o que a vida me ensinou (ROSA, 2001, p. 39).

Ou: "Ser dono definitivo de mim, era o que eu queria, queria. Mas Diadorim sabia disso, parece que náo deixava [...]” (ROSA, 2001, p. 54) e: "O jagunço Riobaldo. Fui eu? Fui e não fui. Não fui! - porque não sou, não quero ser. Deus esteja!” (ROSA, 2001, p. 232).

É importante, nesse sentido, tomar como ponto de reflexáo o caráter de sujeito ${ }^{14}$ na teoria da enunciação de Émile Benveniste: ele "ancorou" a subjetividade à língua: eu propondo-se como locutor que mobiliza, a partir de si, uma ressignificação da língua, ao se configurar como sujeito de determinada enunciação, mais que, ao enunciar, instaura um interlocutor, o $t u$, e assim se estabelece a intersubjetividade ${ }^{15}$ na língua. $\mathrm{O}$ mecanismo de emprego da língua afeta a língua inteira, e a subjetividade só é possível a partir da relaçáo do $e u$ com o $t u$ a propósito d'ele. "O conjunto trinitário [eu-tu/ele] regula as relaçóes subjetivas e intersubjetivas do homem ${ }^{16 "}$ (CAVALHEIRO, 2010, p. 41).

A construção, ou a busca de sua própria compreensão como sujeito, passa por um processo de tensáo notável em toda sua narrativa. Mas esse processo de tensão está justamente, como já antes dito, diretamente relacionado ao seu interlocutor - o "senhor", a propósito de um terceiro, Reinaldo-Diadorim.

Agora, verificar-se-á a posição que Reinaldo-Diadorim desempenha para Riobaldo saber de si. Passos (2008) escreve que "a lembrança de Diadorim começa às margens do Rio Sáo Francisco", e que, "Menina, ela surge travestida no primeiro encontro com Riobaldo, criando-se o enigma que, paralelamente ao pacto com o demônio, ancorará a trama do romance

${ }^{14} \mathrm{Na}$ teoria benvenistiana, o sujeito pode ser caracterizado não como "uma visão egocêntrica, idealista, psicologizante do sujeito [...]", ou seja, "não comporta o estudo do sujeito como entidade [...]" mas "as marcas da enunciação do sujeito no enunciado" (FLORES; SILVA; LICHTENBERG; WEIGERT, 2008, p. 25-27). Nessa mesma interpretação, Cavalheiro aponta não o sujeito, mas sua representação na língua (2010, p. 52).

15 "Inter-relaçáo constitutiva da enunciação que pressupóe o eu e o outro mutuamente implicados” (FLORES; BARBISAN; FINATTO; TEIXEIRA, 2009, p. 146)

${ }^{16}$ Sentido antropológico. 
e as incertezas do narrador" (ROSA, 2001, p. 65). É por causa de Diadorim que Riobaldo narra toda a trama, como que a costurando ao redor desse enigma. $\mathrm{O}$ tom confessional (de revelar, aos poucos, seu amor) já aparece em algumas partes da narrativa, em princípio como "coisas divagadas", "contadas fora" do que seria a narrativa principal - a guerra - como faz crer Riobaldo:

Arfei. Concebi que vinham, me matavam. Nem fazia mal, me importei não. Assim, uns momentos, ao menos eu guardava a licença de prazo para me descansar. Conforme pensei em Diadorim. Só pensava era nele. Um Joâo-gongo cantou. Eu queria morrer pensando em meu amigo Diadorim, mano-oh-mano, que estava na Serra do Pau d'Arco, quase na divisa baiana, com nossa outra metade dos sô-candelários...Com meu amigo Diadorim me abraçava, sentimento meu ia-voava reto para ele...Ai arre, mas: que esta minha boca não tem ordem nenhuma. Estou contando fora, coisas divagadas! No senhor me fio? (ROSA, 2001, p. 37).

O nome Diadorim permanece como significante que o designa somente quando estivesse junto com Riobaldo, já que, para o bando, ele é Reinaldo: “- "Pois então: o meu nome verdadeiro, é Diadorim... guarda este meu segredo. Sempre, quando sozinhos a gente estiver, é de Diadorim que você deve de me chamar, digo e peço, Riobaldo..." (ROSA, 2001, p. 172). Esse enigma vai criar o jogo de revelar/esconder ${ }^{17}$ do corpo (e, logo, da identidade feminina do jagunço Reinaldo), levando Riobaldo aos seus tormentos: "Mas o mal de mim, doendo e vindo, é que eu tive de compensar, numa mão e noutra, amor com amor. Se pode? Vem horas, digo: se um aquele amor veio de Deus, como veio então - o outro?...Todo tormento" (ROSA, 2001, p. 156).

Esse é o ponto de desestabilização, que faz com que a narração de Riobaldo prolongue-se, e a roupagem (vestimenta e comportamento) de Diadorim não aparece como disfarce, ou usurpação, mas a constituição de uma identidade - a de Diadorim, faces de um mesmo (Reinaldo, Deodorina) que são várias. A identidade desse personagem também aparece fragmentada, estilhaçada, ou melhor, diluída em toda a narração, formando pontos obscuros, passagens incompreensivas, que irão se esclarecendo ao final da narrativa, até a morte que, por fim, em desfecho, revelará o enigma entâo encoberto, descoberto na nudez do jagunço - "corpo de uma mulher,

${ }^{17}$ Kathrin Rosenfield escreve que "o esconde-esconde do gênero Diadorim-Deodorina apresenta ao leitor uma charada homo-heterossexual" e que o "que vemos nesse amor depende inteiramente da amplidão ou estreiteza imaginativa de cada leitor” (2008, p. 229). 
moça perfeita..." (ROSA, 2001, p. 615).

$\mathrm{Na}$ luta interior por denegar esse amor e querê-lo, Riobaldo vai iniciar sua narraçáo convocando seu ouvinte. Para Passos (2008, p. 67), ao reconstituir seu passado, "desfazer laços e fios que se desdobram no presente impelem Riobaldo a rememorar", há "a história pessoal, sustentada por uma cegueira que agora se evidencia" e "produz sua reelaboração [...] e, nela, a inserção da singularidade de Diadorim". Também é por causa de Diadorim que Riobaldo permanece no bando como jagunço, mesmo esclarecendo: "a verdade que diga, eu achava que náo tinha nascido para aquilo, de ser sempre jagunço não gostava” (ROSA, 2001, p. 82). É por meio de Reinaldo/ Diadorim que Riobaldo conhece outras facetas de si, tais como a de ser jagunço e ter sensibilidade em "apreciar essas belezas sem dono do sertáo" (ROSA, 2001, p. 42).

Há, ainda, uma relação metonímica entre o corpo da narrativa e o corpo de Diadorim ${ }^{18}$. A morte de Diadorim é convertida em narração, que vai perfazendo e costurando/trançando os pontos obscuros, e por isso só com o desenrolar, a continuaçáo e insistência no contar, é que o sertão pela palavra vai sendo cruzado novamente por Riobaldo.

$\mathrm{O}$ ele da narrativa, a não pessoa, fantasma e mal a ser expurgado, é a morte de Diadorim, a matéria vertente em que se converte, por fim, toda a narrativa, uma vez que é ela quem motiva Riobaldo a contar e revelar o fato: a morte e descoberta do corpo de mulher debaixo da figura do jagunço. Assim, a descoberta de si ocorre a partir da revelação de que Diadorim é mulher, utilizando para tanto a estratégia do duplo ( $t u$-o "senhor") de si (eu-Riobaldo) no decorrer do relato, ou seja, o seu duplo será aquele que desconhece os fatos e, logo, não sabe ainda, ao início da narração, que Diadorim trata-se de uma mulher: "Diadorim desconversou, e se sumiu, por lá, por aí, consoante a esquisitice dele, de sempre às vezes desaparecer e tornar a aparecer, sem menos" (ROSA, 2001, p. 78), e:

\footnotetext{
${ }^{18}$ Essa indicação interpretativa está em Cleusa Passos (2003, p. 66-67), ao escrever que a donzelice de Diadorim é "algo inscrito em passagens textuais dispersas", e o não-saber, nó da narrativa, "trajetória e sina a ser desenredada [...] com a morte do objeto desejado" é o que provoca o "impulso de contar e ser escutado". Cleonice Mourão (2000) observa também que a outra face do personagem Reinaldo (Diadorim) funciona como "catalizadora da ode" que "não desaparece como função encantatória” que produziu a narração. Kathrin Rosenfield aponta para este mesmo sentido na obra ao mostrar que a surpresa e a dor do espectador Riobaldo ao assistir a morte de Diadorim levam-no a representá-la narrativamente, o que, numa análise da dimensão trágica do romance, corresponde, para o leitor, "ao conceito de katharsis aristotélica" (2006, p. 342).
} 
O senhor mesmo, o senhor pode imaginar de ver um corpo claro e virgem de moça, morto à mão, esfaqueado, tinto todo do seu sangue, e os lábios e a boca descorados no branquiço, os olhos dum terminado estilo, meio abertos meio fechados? E essa moça de quem o senhor gostou, que era um destino e uma surda esperança em sua vida?! Ah, Diadorim...E tantos anos já se passaram (ROSA, 2001, p. 207).

Através desse duplo, Riobaldo encena em sua fala todo o processo de descoberta de Diadorim, revisitando, enquanto narra, as pistas obscuras dessa identidade dispersa no seu passado. Também, como um processo de expurgar os fantasmas desse passado (seu tormento), representados na morte de Diadorim e na não-realização, portanto, do seu objeto de amor, ele revive, via narração, esse acontecimento. Por isso, para poder revivê-lo, tentando recapitular/captar cada ponto disperso, ele se reinventa num interlocutor que desconhece, como ele, Riobaldo, no começo, o que no passado o Riobaldo personagem desconhecia.

Desse modo, assim como ele passou a conhecer por inteiro aquilo que era fragmento ${ }^{19}$, ele refaz esse mesmo leitmotiv no seu duplo - o "senhor" - e igualmente experimenta, outra vez, a descoberta, feita ao fim; os elementos dispersos do corpo também disperso se contornam, vão ganhando forma, à medida que a narração aproxima-se do fim, e a morte revela o enigma: "Ah, e a Mulher rogava: - Que trouxessem o corpo daquele rapaz moço, vistoso, o dos olhos muito verdes...Eu desguisei." (ROSA, 2001, p. 614), e:

Eu conheci! Como em todo tempo antes eu não contei ao senhor - e mercê peço: - mas para o senhor divulgar comigo, a par, justo o travo de tanto segredo, sabendo somente no átimo em que eu também só soube...Que Diadorim era corpo de mulher, moça perfeita...Estarreci. A dor náo pode mais que a surpresa. A coice d'arma, de coronha... (ROSA, 2001, p. 615)

O fechamento se dá com o registro de batismo (o significante real), que revela o nome verdadeiro de Diadorim:

Da matriz de Itacambira, onde tem tantos mortos enterrados. Lá ela foi levada à pia. Lá registrada, assim. Em um 11 de setembro de 1800 e tantos...O senhor lê. De Maria Deodorina da Fé Bettancourt Marins - que nasceu para o dever de guerrar e nunca ter medo, sem gozo de amor...Reze o

19Para Kathrin Rosenfield (2006, p. 349-350), “é o relato - o enredamento poético (o mythos trágico de Aristóteles) - que instala Riobaldo na posição dupla e dúbia de ator e espectador. Esse último vê o que o primeiro náo conseguia enxergar, distinguindo nas "neblinas de Siruiz" e nas "vertentes do viver" formas paradigmáticas da finitude humana". 
senhor, por essa minha alma. O senhor acha que a vida é tristonha? (ROSA, 2001, p. 620-621).

Uma vez revelado/des-coberto/desatado o "nó" da narrativa, entáo ela pode ser concluída, a travessia dolorosa pelo passado está feita. Riobaldo narrador cala as vozes antigas, e termina o corpo da narrativa, já concluído/ já revelado: "Cerro. O senhor me vê. Contei tudo. [...] Amável o senhor me ouviu [...] Amigos somos. Nonada. O diabo não há! É o que eu digo, se for... Existe é homem humano. Travessia” (ROSA, 2001, p. 624).

Para finalizar, a criação de um tu-imaginário (o "senhor"), que se caracteriza como o duplo do narrador, nesta proposta de leitura, tornase verossímil por dois pontos particulares analisados: 1) o interlocutor é interditado de sua fala (sua presença é reiterada, por conseguinte, pelo sujeito-narrador, e dela dependente); 2) o narrador-protagonista está em processo de um monólogo (ou monodiálogo, para Fantini [2003, p. 75]), com um ouvinte imaginado como um outro diferente de si, mas com pontos de contato. Esse interlocutor, como igualmente já foi visto, possibilitará Riobaldo enunciar, mesmo sendo esse $t u$ um imaginário.

Mostramos ainda como, sendo resultado de "um conflito psíquico que cria o duplo" e "projeção da desordem íntima" (BRAVO, 1998, p. 263), o duplo de Riobaldo - o "senhor", também caracterizado aqui como (tu)-destinatário, (tu)-interlocutor, surge dentro da narrativa interditado de tornar-se eu (no jogo de reversibilidade dos pronomes eu-tu), uma vez que apenas o narrador-protagonista fala e modula toda sua narração enunciando no lugar do seu alocutório.

Vimos que, numa primeira leitura, o "senhor" poderia ser considerado como resultado/resultante da "cisão do ego" (BENVENISTE, 1989, p. 88) de Riobaldo e, por isso, admitir esse ouvinte como um diálogo interior entre eu ouvinte e eu interlocutor. Pudemos verificar que, se assim se configurasse esse diálogo, o tu-"senhor" seria apenas um simulacro do $e u$, e mesmo um monólogo, conforme Benveniste, instaura a enunciação da/na língua. Observamos também que, se à primeira análise essa leitura tornava-se viável, a percepçáo de que, mesmo que não houvesse reversibilidade, do $t u$ tornarse $e$, também não poderia caracterizar esse "senhor" como $e l e$, a não pessoa benvenistiana, e apresentá-lo como um ausente/presente da fala do narrador. 
A questão que ia perfazendo nossa análise observou, entretanto, que caracterizar o senhor como fala interior (eu ouvinte) fazia ignorar, conforme pontuou Kathrin Rosenfield (2003, p. 363), que, mesmo que não adquira a plasticidade de um caráter individualizado, ele está ficcionalmente presente até o final do romance e não pode ser negligenciado. Bem como João Adolfo Hansen (2000, p. 48-49) mostra que na sua fala agônica Riobaldo neutraliza seu interlocutor, ou Márcia Morais (s.d., p. 5) que observou que Riobaldo instaura um "semi-diálogo formalizado", que "finge um diálogo interior."

Ao utilizarmos a tríade pronominal benvenistiana para realizar uma análise enunciativa do duplo na obra eleita, analisamos narrador $\mathrm{e}$ interlocutor dentro desse quadro enunciativo. O quadro formal da enunciação fixa, ou melhor, mostra as posiçóes ocupadas pelos personagens: o narrador/protagonista, o "senhor", duplo de Riobaldo, levando em conta o grau de presença que aquele atribui a este, e a presença de ReinaldoDiadorim. Pudemos perceber, assim, que o eu e o duplo, entre narradorprotagonista e interlocutor, visto a partir da análise enunciativa, nos deu subsídios para caracterizar esse "senhor" como duplo de Riobaldo (eu-eu mesmo, tu-eu).

\section{Referências}

BRAVO, Nicole Fernandez. Duplo. In: BRUNEL, Pierre (Org.). Dicionário de mitos literários. 2. ed. Trad. Carlos Sussekind et al. Rio de Janeiro: J. Olympio, 1998. p. 261-287.

BENVENISTE. Émile. Da subjetividade na linguagem. In: Problemas de linguística geral I. Trad. Maria da Gloria Novak e Maria Luiza Neri. Campinas: Pontes, 1991. p. 284-293.

O aparelho formal da enunciação. In: Problemas de

Linguística Geral II. Trad.: Eduardo Guimarães et. al. Campinas: Pontes, 1989. p. 81-90.

CAVALHEIRO, Juciane. Literatura e Enunciação. Manaus: UEA Ediçôes, 2010.

COUTINHO, Eduardo F. Discursos, fronteiras e limites na obra de Guimarães Rosa. In: FANTINI SCARPELLI, Marli de Oliveira (Org.). A poética migrante de Guimaráes Rosa. Belo Horizonte: Editora UFMG, 2008. p. 365-378.

DUFOUR, Dany-Robert. Os mistérios da trindade. Trad. Dulce Duque 
Estrada. Rio de Janeiro: Companhia de Freud, 2000.

FANTINI SCARPELLI, Marli de Oliveira. Grande sertão: fronteiras. In: . Guimaráes Rosa: fronteiras, margens, passagens. Cotia: Ateliê Editorial; São Paulo: Editora SENAC São Paulo, 2003. p. 269-282.

FLORES, Valdir do Nascimento; BARBISAN, Leci Borges; FINATTO, Maria José B.; TEIXEIRA, Marlene. Dicionário de linguística da enunciaçáo. São Paulo: Contexto, 2009.

FLORES, Valdir do Nascimento; SILVA, Silvana; LICHTENBERG, Sônia; WEIGERT, Thaís. Enunciaçáo e gramática. São Paulo: Contexto, 2008.

GUIMARÁES ROSA, João. Grande sertáo: veredas. 19. ed. Rio de Janeiro: Nova Fronteira, 2001.

HANSEN, João Adolfo. O O: a ficção da literatura em Grande Sertão: Veredas. 1. ed. São Paulo: Hedra, 2000.

MORAIS, Márcia Marques de. Sujeito e Discurso: algumas consideraçóes sobre a análise do discurso do narrador em "Grande Sertão: Veredas". Portal Puc-Minas. [s.d.]. Disponível em: $\leq$ http://portal.pucminas.br/imagedb/ documento/DOC DSC NOME ARQUI20120903161941.pdf >. Acesso em: 20 abr. 2010.

MOURÃO, Cleonice Paes Barreto. Diadorim: o corpo nu da narração. In: DUARTE, Lélia Parreira et al. (Orgs.). Veredas de Rosa. Cátedra Jorge de Sena: Belo Horizonte, 2000. p. 158-163.

OLIVEIRA, Luiz Cláudio Vieira de. Palavras do sertáo. Revista Discutindo literatura especial, São Paulo, Escala, ano 1, n. 4, p. 15-20, 2008.

PASSOS, Cleusa Rios Pinheiro. Diadorim: dia da lua. In: FANTINI SCARPELLI, Marli de Oliveira (Org.). A poética migrante de Guimarães Rosa. Belo Horizonte: Editora UFMG, 2008. p. 64-88.

ROSENFIELD, Kathrin Holzermayr. Desenveredando Rosa: J. G. Rosa e outros ensaios. Rio de Janeiro: Topbooks, 2006.

. Do "volúvel" Machado ao Rosa "romântico": reflexôes sobre o uso da(s) ironia(s) no Brasil. In: FANTINI SCARPELLI, Marli de Oliveira (Org.). A poética migrante de Guimaráes Rosa. Belo Horizonte: UFMG, 2008. p. 64-88. 